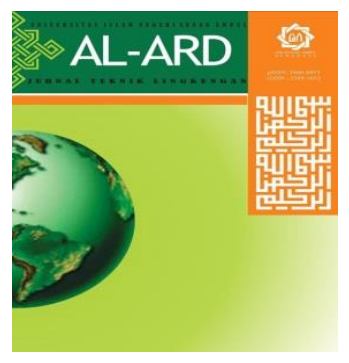

Al-Ard: Jurnal Teknik Lingkungan

Vol.7 No.1 - September 2021 (hal. 01-08)

http://jurnalsaintek.uinsby.ac.id/index.php/alard/index
Al-Ard:

Jurnal

Teknik Lingkungan

\title{
Tofu Wastewater Treatment with the Growth Suspended Microorganism Using Different Air Flowrate Rizka Novembrianto ${ }^{1,}$, Restu Hikmah Ayu $\mathbf{M}^{2}$, Firra Rosariawari ${ }^{3}$ \\ 1,2,3 UPN "Veteran" Jawa Timur, Surabaya, Indonesia \\ *rizka.tl@upnjatim.ac.id
}

\begin{abstract}
The liquid waste of tofu from many industries is mostly discharged into the river and caused pollution. This research discusses the processing of tofu wastewater with the aim of reducing and controlling the levels of $\mathrm{pH}$, BOD, COD, TSS, and temperature so as not to pollute the environment when dumped into rivers or other suitable places by simple reactors in few days. The water treatment process using bacterial from wastewater as a medium seems promising to develop since it does need any microorganism stater or other media like glucose. The method that used in this research are seeding, acclimatization, and running with recirculation process. During the process of microorganism growth (seeding), the peak of MLSS was obtained on day 6 with $1560 \mathrm{mg} / \mathrm{L}$. The other reason is wastewater from their wastewater processing is more suitable for microorganism cultivation because its effluent contains significant beneficial nutrients and less of toxic compounds and harmful substances that interface with the growth of microorganisms In same condition ( $\mathrm{pH}$ and Temperature) in the Acclimatization process can reach $77.45 \%$ after 7 days of treatment. After the detention time (18 hours) the results of COD number also greatly decrease with 5 hours recirculation with 8 $\mathrm{L} / \mathrm{min}$ air flowrate and $86,51 \%$ percentage of COD parameter decreased. This research is running in a laboratory scale, which makes this pilot plant must be recalculated to bring in large scale applications. However, this technology represents an effective, economic, and environmentally friendly process for tofu wastewater treatment.

Keywords: tofu wastewater, growth suspended microorganism, air flow rate
\end{abstract}

\begin{abstract}
Abstrak
Limbah cair tahu dari berbagai industri sebagian besar dibuang ke sungai dan menimbulkan pencemaran. Penelitian ini membahas tentang pengolahan air limbah tahu dengan tujuan untuk menurunkan dan mengontrol kadar pH, BOD, COD, TSS, dan suhu agar tidak mencemari lingkungan saat dibuang ke sungai atau tempat lain yang sesuai dengan reaktor sederhana dalam beberapa hari. Proses pengolahan air menggunakan bakteri dari air limbah sebagai media tampaknya menjanjikan untuk dikembangkan karena memang membutuhkan stater mikroorganisme atau media lain seperti glukosa. Metode yang digunakan dalam penelitian ini adalah penyemaian mikroorganisme, aklimatisasi, dan running dengan proses resirkulasi. Selama proses pertumbuhan mikroorganisme (penyemaian), puncak MLSS diperoleh pada hari ke-6 sebesar $1560 \mathrm{mg} / \mathrm{L}$. Alasan lainnya adalah air limbah dari pengolahan air limbah mereka lebih cocok untuk budidaya mikroorganisme karena limbahnya mengandung nutrisi bermanfaat yang signifikan dan lebih sedikit senyawa beracun dan zat berbahaya yang berinteraksi dengan pertumbuhan mikroorganisme Dalam kondisi yang sama (pH dan Suhu) dalam proses Aklimatisasi dapat mencapai 77,45\% setelah 7 hari pengobatan. Setelah waktu detensi (18 jam) hasil bilangan COD juga sangat menurun dengan resirkulasi 5 jam dengan debit udara 8 $\mathrm{L} /$ menit dan persentase parameter COD turun 86,51 \%. Penelitian ini berjalan dalam skala laboratorium, yang membuat pilot plant ini harus dihitung ulang untuk digunakan dalam aplikasi skala besar. Namun, teknologi ini merupakan proses yang efektif, ekonomis, dan ramah lingkungan untuk pengolahan air limbah tahu. Kata kunci: limbah cair tahu, pertumbuhan mikroorganisme tersuspensi, laju aliran udara
\end{abstract}

\section{INTRODUCTION}

Tofu is a processed-food made from soybeans. Tofu is generally consumed as the main protein sources in Indonesia. For a long time, tofu has been the most popular food throughout Asia. Tofu contains a lot of protein and vitamins (Faisal, 2016). In addition, tofu protein is 35 percent greater than food from unprocessed plants or animals. The soy protein in tofu contains eight essential amino acids when processed in the human body. It is 
common knowledge that there are no important differences between animal and plant proteins. From a body perspective, the amount of protein used in $1 / 2$ cup of soybeans is no different from that contained in 5 ounces of steak (Shurtleff, 1975). Soybeans at low prices do not contain cholesterol. This is the reason why many people like soy-based foods, one of which is tofu. The increasing of consumption needs, the production of tofu is also getting bigger. (Ridha, 2015) reported that the number of micro small and mediumenterprises (MSMEs) producing tofu in Indonesia is around 85,000 businesses with 285,000 workers, of whom 40-50\% are woman. According to the Ministry of Industry, there are around 203 large companies throughout Indonesia and the largest companies are located in East Java with 86 companies. Tofu factories in Indonesia annually produce around 2.56 million tons of soybeans in the process. On this amount, each tofu factories produce about 20 million $\mathrm{m}^{3}$ /year of liquid waste and about 1024 million tons of solid waste (Sintawardani, 2011). For each $100 \mathrm{~kg}$ soybean used for the production, it takes water in approximately $1.5-2 \mathrm{~m}^{3}$. On total $100 \mathrm{~kg}$ soybean production, tofu industries generally produce solid waste for about $40 \%$ (Nur, 1991).

The solid waste of tofu contains protein (23.35\%), water $(10,53 \%)$, fat $(5.54 \%)$, sugar (26.92\%), ash (17.03\%), and crude fiber (16.53\%) (Bapedal, 1994). (Faisal 2016) reported that liquid waste of making tofu contains in great quantities organic substances, Chemical Oxygen Demand (COD) of 7,500$14,000 \mathrm{mg} / \mathrm{L}$, Biochemical Oxygen Demand (BOD 5) of $6,000-8,000 \mathrm{mg} / \mathrm{L}$, tempe temperature reached $40-46^{\circ} \mathrm{C}$ and low acidity at $\mathrm{pH}$ of 5-6.

This research also provide a preliminary study to make small-scale tofu industrial wastewater treatment easy and efficient. An alternative method for treating small-scale tofu industrial wastewater is using an activated sludge system. The treatment scheme of wastewater from washing or soaking tofu is pumped to a packed wastewater treatment unit consisting of an aeration tank and a sedimentation tank. In this aeration tank, wastewater is treated by activated microorganisms. After a certain time from the aeration tank, then continued to the processing of the sedimentation to settle sediment (Nagwekar, 2014).

Liquid Waste Quality Standard for the industry or Other Exertion: Regulation of the Governor of East Java No. 72 Year of 2013 declared regulation to maintain environmental by controlling amount of parameters, can be seen in Table-1.

Tabel 1. Liquid Waste Quality Standard for the Processed-Soybean Industry (Tofu)

Parameter Standar Maximal

\begin{tabular}{|c|c|}
\hline $\mathrm{BOD}_{5}(\mathrm{mg} / \mathrm{L})$ & 150 \\
\hline $\mathrm{COD}(\mathrm{mg} / \mathrm{L})$ & 300 \\
\hline TSS (mg/L) & 100 \\
\hline $\mathrm{pH}(\mathrm{mg} / \mathrm{L})$ & $6.0-9.0$ \\
\hline $\begin{array}{l}\text { Maximum Capacity WWTP } \\
\text { (m3/ton) }\end{array}$ & 20 \\
\hline
\end{tabular}
Year of 2013)

The liquid waste of tofu from many industries are mostly discharged into the river, definitely kill the biotic lives, reduce the quality of water due to high organic substances and cause a bad and pollution on the surface to the ground water. Unfortunately, those industries still use environmentally damaging production in process. There are problems in processed soybean-based food industry such as inadequate, ineffieciency waste disposal and low awareness about new efficient technology (Ridha, 2015). The tofu waste which dumpes into the river without any treatment might cause the death of organism lived in river, damaging ecosystems and harming human who use the river for washing, bathing, fishing, etc. For this reason, due to the large amount of liquid tofu waste that over passed Liquid Waste Quality Standard for Industry, it is necessary to process tofu waste first before being discharged into rivers or other suitable places. Therefore, this research discusses the processing of tofu waste with the aim of reducing and controlling the levels of BOD, COD, MLSS, DO and temperature so as not to pollute the environment when dumped into rivers or other suitable places by simple reactors in few days. This simple way can be a solution for tofu industries because it only requires simple reactors with only a few days. Although the time is short but the impact is important for the environment due to the decrease in BOD and COD.

\section{MATERIALS AND METHODS}

The tofu waste water that used in this research were collected from one of tofu home 
industry in Sidoarjo, Indonesia. In this research two different reactors were used, seeding and acclimatization. The $\mathrm{pH}$ that used in this research is $3.4 \pm 0.1$, this number of $\mathrm{pH}$ is the natural $\mathrm{pH}$ that tofu industries produce. Standart method to analyze the sample can be seen in Table 2.

Table 2. Standart Method to Analyze The Sample

\begin{tabular}{ll}
\hline Parameters & Standard Method \\
\hline BOD & SNI 6989.72:2009 \\
COD & SNI 6989.2:2019 \\
TSS & SNI 06-6989.3-2004 \\
\hline
\end{tabular}

Before this research, testing COD and DO in inlet source is important due to know the differences between before and after research. The levels of DO and COD between tofu factories that used in this sample differ from other tofu factories depending on the use of vinegar in the process. To obtain the desired results, this research is estimated at 13 days for seeding and continued 7 days for acclimatization, 1 days was spent to run this research. Flowchart of research method can be seen in Figure 1.

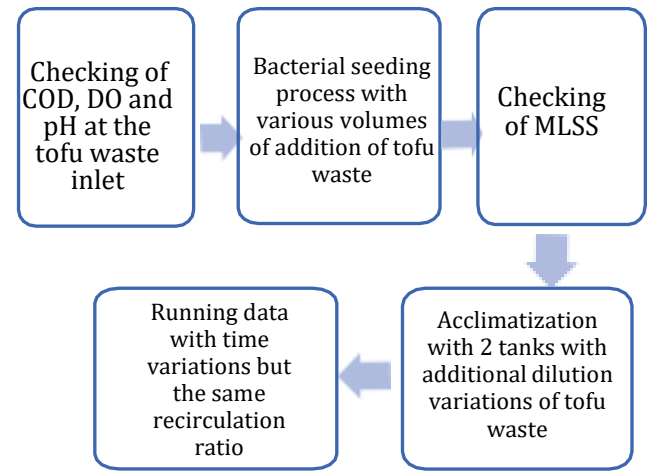

Figure 1. Flowchart of Research Method

\section{a. Seeding Process}

Seeding process on this research was run with an air pump oxygen with $4 \mathrm{~L} /$ minutes capacity that attached on reactor. On the first day, one liter of tofu waste has added to the reactor then add one liter each day until it reach 5L in fifth day. In the seeding process, to avoid the formation of a lot of foam, the air duct holes are made bigger this method makes the air bubbles become large, this affects the formation of foam. If the air bubbles are getting smaller, the seeding process will produce more bubles. For this reason, the air bubbles are made larger in order to produce or minimize the foam produced. In the seeding process when the oxidation process uses an air flow of $4 \mathrm{~L} / \mathrm{min}$, it is greater than Zahra, et al., (2015) using 3 $\mathrm{L} / \mathrm{min}$.

\section{b. Acclimatization process}

The acclimatization process run after the seeding process, this process use waste water with $\mathrm{pH}$ of $3.4 \pm 0.1$. This acclimatization requires 2 tanks, with a recirculation that connect each other with recirculation air flowrate $100 \mathrm{~mL} / \mathrm{min}$. The acclimatization stage starts from $20 \%$ of the organic content at the beginning into the reactor, respectively $40 \%, 60 \%, 80 \%$ until $100 \%$ of maximum capacity. In the $100 \%$ condition, it was carried out for several days until the outlet results become stable. At the acclimation process detention time of 24 hours is used. Design reactor in acclimatization process can be seen in Figure 2.

\section{c. Running process}

In aeration tank, detention time 18 hours were given to know the resistance of bacteria. This condition compares with Astuti, (2019) which uses 18 hours of detention time but uses anaerobic and aerobic process methods. Sample was analized in every hours in 5 hours with various air pump flowrate $(4 \mathrm{~L} / \mathrm{min}$ and 8 $\mathrm{L} / \mathrm{min}$ ) at outlet sedimentation tank. On this recirculation process, one air pump is used. In the running process, the condition of the $\mathrm{pH}$ value and temperature as a control function in controlling wastewater treatment.

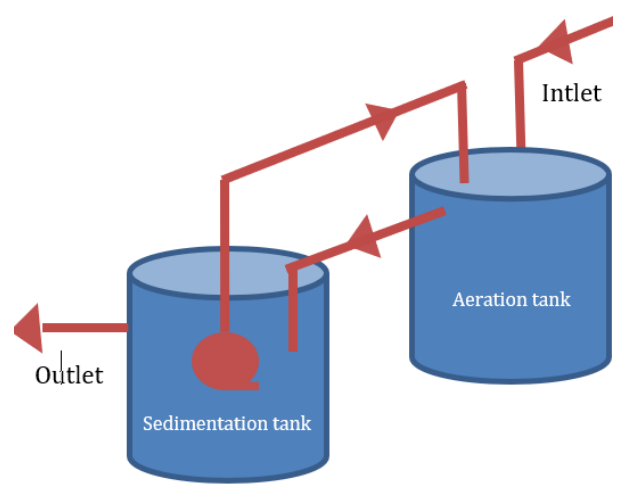

Figure 2. Design Reactor in Acclimatization Process

Data analysis used the following equation: Efficiency $=\left(\left(\mathrm{C}_{\text {in }}-\mathrm{C}_{\text {out }}\right) / \mathrm{C}_{\text {out }}\right) \times 100 \%$

Where :

$$
\mathrm{C}_{\text {in }}=\text { inlet concentration }
$$$$
\mathrm{C}_{\text {out }}=\text { outlet concentration }
$$ 


\section{RESULTS AND DISCUSSIONS}

The results of the initial analysis of the tofu factory wastewater that have been carried out in this experiment can be seen on Table 3 .

Table 3. Results Analysis for Waste Water

\begin{tabular}{cc}
\hline Parameters & Result \\
\hline BOD & 1428 \\
COD & 6077 \\
TSS & 1280 \\
\hline \multicolumn{2}{l}{ (Source: Research Result, 2021) }
\end{tabular}

Table 3 above represent the organic content of the tofu industry. This number is quite high compare to Regulation of the Governor of East Java No. 72 Year of 2013 about water quality standards soybean processed industrial waste. The standard for BOD, COD and TSS are 150, 300 and $100 \mathrm{mg} / \mathrm{L}$.

\section{a. Seeding}

Mostly, the seeding in the process in tofu waste water treatment is using attached growth bacteria, this research use suspended growth microorganism that does not use media and only requires oxygen in the process.

Table 4. Results Analysis for Waste Water Parameters Day 1-13

\begin{tabular}{ccccc}
\hline & \multicolumn{4}{c}{ Parameters } \\
\cline { 2 - 5 } Day & MLSS & COD & pH & Temperature \\
\hline 1 & 800 & 6039 & 7.1 & 29 \\
\hline 2 & 855 & 5020 & 8.1 & 29 \\
\hline 3 & 1080 & 3373 & 8.3 & 29 \\
\hline 4 & 913 & 3059 & 8.2 & 30 \\
\hline 5 & 1400 & 2745 & 8.4 & 29 \\
\hline 6 & 1560 & 2203 & 8.6 & 28 \\
\hline 7 & 1280 & 2015 & 8.9 & 28 \\
\hline 8 & 1110 & 1992 & 8.9 & 29 \\
\hline 9 & 750 & 1824 & 8.9 & 29 \\
\hline 10 & 844 & 1725 & 8.8 & 29 \\
\hline 11 & 842 & 1255 & 8.8 & 32 \\
\hline 13 & 952 & 1490 & 8.8 & 28 \\
\hline (Source: Research Result, 2021)
\end{tabular}

In carrying out the seeding process, the thing to consider is $\mathrm{pH}$. In the initial analysis, with $\mathrm{pH}$ range of $3.4 \pm 0.1$. With the addition of the incoming air rate is not too large, within 24 hours, the $\mathrm{pH}$ shows the number of 7.1. The rapid process of raising $\mathrm{pH}$ represent the right air velocity application process.

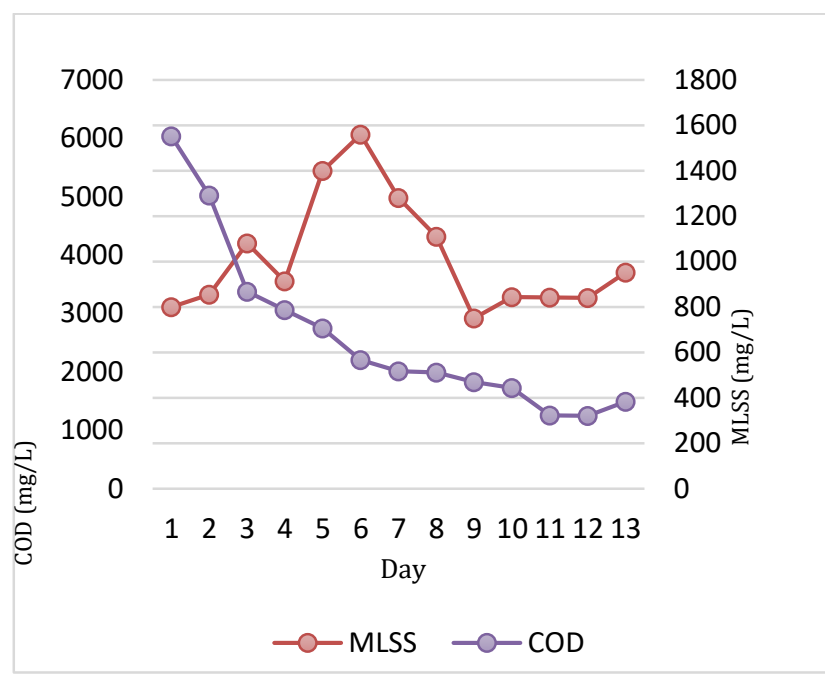

Figure 3. The Effect of Seeding Process on MLSS and COD

Results analysis for waste water parameters day 1-13 can be seen in Table 4 . Figure 3 shows the linear graph MLSS and COD from day 1 until 13 . The growth of microorganisms was represented by the amount of MLSS, on the first day after being given the air had a value of $800 \mathrm{mg} / \mathrm{L}$. The data from MLSS reach the peak in day 6 then rapidly decrease in day 7 before get equilibrium in day 9. Highest MLSS content at $1560 \mathrm{mg} / \mathrm{L}$. High MLSS indicates the number of microorganisms in high activated sludge, capable of multiplying by utilize organic materials and nutrients found in waste (Fitrahani, 2012). In this research the bacterial from waste water was used as medium to culture of various microorganism so there is no need to add the bacteria stater or glucose, this method seems promising alternative in waste water treatment process (Ding et al, 2015). Wastewater from food processing is more suitable for bacteria cultivation because its effluent contains significant beneficial nutrienst and less of toxic compounds and harmful substances that interface with the growth of bacteria (Tan et al, 2014).

The number of COD shows different patern with the MLSS number. COD number extremely decrease since day 1 until day 6 and slightly different in day 7 until 13 due to the decomposition of organic components by microorganisms.

\section{b. Acclimatization}

Acclimatization process runs after the seeding process. This process begans on day 14 until 7 days after. From these days, it is reviewed whether the COD and DO values are almost relatively significant (Figure 4). 
Table 5. The Acclimatization Results

\begin{tabular}{ccccccc}
\hline \multicolumn{7}{c}{ Parameters } \\
\hline $\begin{array}{c}\text { COD } \\
\text { inlet } \\
\text { (mg/L) }\end{array}$ & $\begin{array}{c}\text { Do } \\
\text { (mg/L) }\end{array}$ & pH & oC & $\begin{array}{c}\text { COD } \\
\text { outlet } \\
\text { (mg/L) }\end{array}$ & $\begin{array}{c}\text { \% } \\
\text { removal COD } \\
\text { of }\end{array}$ \\
\hline 14 & 1226 & 1.19 & 8.7 & 30 & 1084 & $11.56 \%$ \\
\hline 15 & 2465 & 4.22 & 8.9 & 31 & 1406 & $42.96 \%$ \\
\hline 16 & 3630 & 4.47 & 8.8 & 30 & 1397 & $61.52 \%$ \\
\hline 17 & 4844 & 4.56 & 8.8 & 28 & 1376 & $71.59 \%$ \\
\hline 18 & 6067 & 5.26 & 8.8 & 31 & 1388 & $77.12 \%$ \\
\hline 19 & 6058 & 5.24 & 8.8 & 31 & 1402 & $76.86 \%$ \\
\hline 20 & 6021 & 5.38 & 9.0 & 27 & 1358 & $77.45 \%$ \\
\hline (Source: Research Result, 2021$)$ & & & \\
\hline
\end{tabular}

Table 5. represent stable results within 3 days, on day 18, 19 and 20 the range between 76 and $77 \%$ COD removal results. The effectivity of this process can seen on removal of COD inlet and outlet, on day 20 the removal of COD reach higher removal compare to first day of treatment with the condition $\mathrm{pH} 8.7$ until 9.0 and naturall temperature, the different of temperature may caused of room temperature that maybe change.

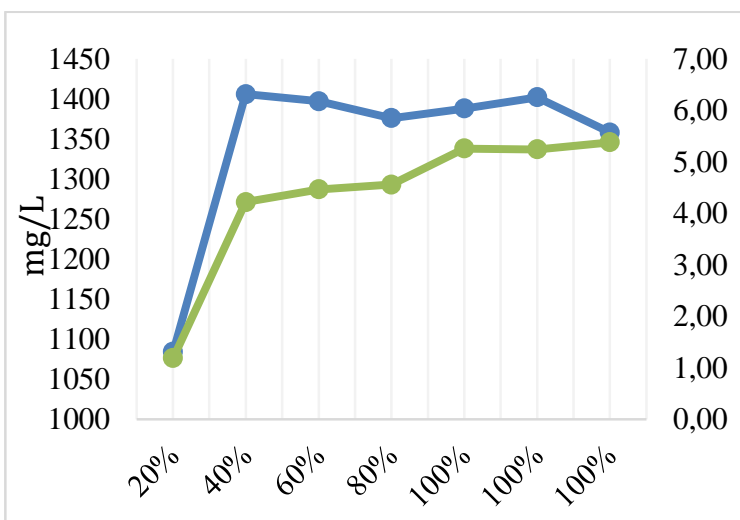

volume organic contain acclimatization in $5 \mathrm{~L} \longrightarrow \mathrm{COD} \longrightarrow \mathrm{DO}$

Figure 4. Amount of DO and COD Outlet During the Acclimatization Process

The amount of DO concentration in waste water greatly increased and start reach equilibrium at $40 \%$ volume due to the increasing of total volume of waste water on acclimazation process. The equilibrium concentration on DO and COD due to increasing the volume of waste water indicate that the waste water ideally use for run this research.

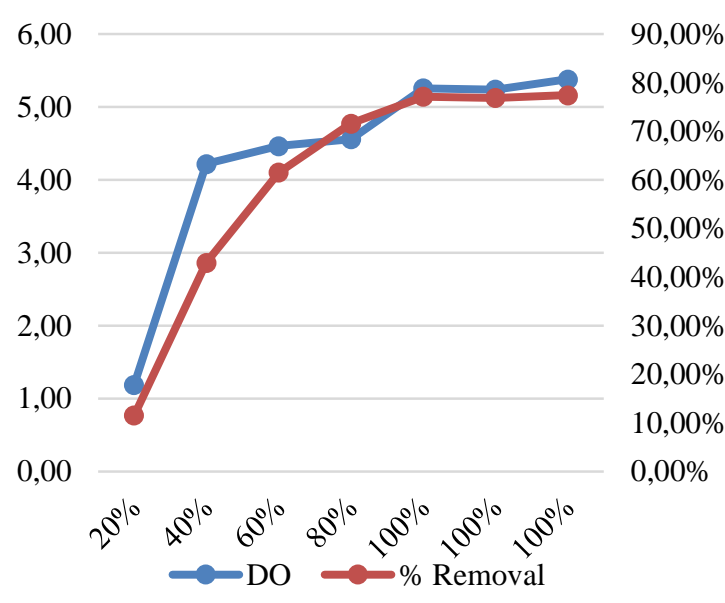

Figure 5. The Relationship between DO and Amount of COD Removal on Water.

On the first day of the acclimation process, the removal percentage was only $11.56 \%$, this caused of dissolved oxygen value was still very low at $1.19 \mathrm{mg} / \mathrm{L}$ so that microorganisms were not optimal in decomposing wastewater Martin, et. al, (2003) also argues that the dissolved oxygen value $\leq 1.1 \mathrm{mg} / \mathrm{L}$ will affect the sludge deposition system.

In addition the concentration of DO represent the same pattern as removal of COD on water. These data indicate that the DO on waste water contribute to amount COD removal on water. The increasing of DO on water is produced by aerator that used during the process, this pattern indicates that the aeration process on this stage is successfully applied. The relationship between do and amount of cod removal on water can be seen in Figure 5.

\section{c. Running}

After reaching a stable state for results efficiency of organic matter and COD, then continuous research with variations air flowrate and analized in every hour. The influent COD content of $6077 \mathrm{mg} / \mathrm{L}$ when entering the reactor during the running process, the results obtained in several number on Table 6.

Table 6. Sample Analysis Result after Detention Time

\begin{tabular}{clrrrrr}
\hline \multirow{2}{*}{$\begin{array}{c}\text { Air } \\
\text { flowrate }\end{array}$} & Parameters & \multicolumn{5}{c}{ hours } \\
\cline { 2 - 7 } & & $\mathbf{1}$ & $\mathbf{2}$ & $\mathbf{3}$ & $\mathbf{4}$ & $\mathbf{5}$ \\
\hline $\begin{array}{c}4 \\
\text { L/min }\end{array}$ & BOD & 323 & 319 & 282 & 275 & 268 \\
\cline { 2 - 7 } & COD & 1302 & 1277 & 1182 & 1174 & 1152 \\
\cline { 2 - 7 } & TSS & 705 & 654 & 522 & 480 & 467 \\
\cline { 2 - 7 } & $\mathrm{pH}$ & 8.2 & 8.3 & 8.4 & 8.4 & 8.4 \\
\cline { 2 - 7 } & $0 \mathrm{C}$ & 28.4 & 29.4 & 30 & 30.5 & 29.6 \\
\hline $\begin{array}{c}8 \\
\text { L/min }\end{array}$ & BOD & 248 & 189 & 178 & 169 & 164 \\
\cline { 2 - 7 } & COD & 1125 & 902 & 892 & 844 & 820 \\
\cline { 2 - 7 } & & & & & &
\end{tabular}




\begin{tabular}{llccccc}
\hline \multirow{2}{*}{$\begin{array}{c}\text { Air } \\
\text { flowrate }\end{array}$} & Parameters & \multicolumn{5}{c}{ hours } \\
\cline { 2 - 7 } & & $\mathbf{1}$ & $\mathbf{2}$ & $\mathbf{3}$ & $\mathbf{4}$ & $\mathbf{5}$ \\
\hline \multirow{4}{*}{} & $\mathrm{TSS}$ & 422 & 295 & 286 & 255 & 240 \\
\cline { 2 - 7 } & $\mathrm{pH}$ & 8.5 & 8.6 & 8.6 & 8.6 & 8.7 \\
\cline { 2 - 7 } & ${ }^{\circ} \mathrm{C}$ & 28.7 & 29.9 & 30.7 & 31 & 30 \\
\hline
\end{tabular}

(Source: Research Result, 2021)

There is a difference in the increase in the $\mathrm{pH}$ value during the running process. For an air rate of $4 \mathrm{~L} / \mathrm{min}$ ranging from $\mathrm{pH} 8.2$ to $\mathrm{pH} 8.4$, this is the same as Matilda's (2016) study which also operates at $\mathrm{pH} 8.2 \pm 0.1$. Medium for the air rate of $8 \mathrm{~L} / \mathrm{min}$ ranging from $\mathrm{pH} 8.5$ to pH 8.7.

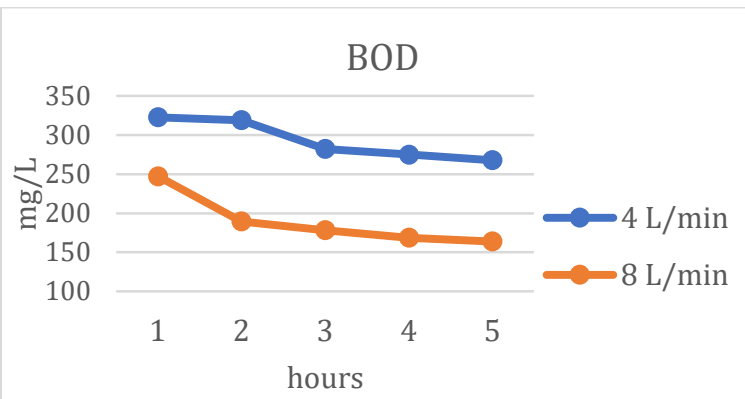

Figure 6. BOD Concentration in $4 \mathrm{~L} / \mathrm{min}$ and $8 \mathrm{~L} / \mathrm{min}$ air Flowrate

Figure 6 shows that after 2 hours BOD decreased significantly with an air rate of 4 $\mathrm{L} / \mathrm{min}$ while for $8 \mathrm{~L} / \mathrm{min}$ it decreased significantly after 3 hours of deposition. Both variations after experiencing a significant decrease and then gradually decreased slowly. Various air flowrate $(4 \mathrm{~L} / \mathrm{min}$ and $8 \mathrm{~L} / \mathrm{min}$ ) were analyze to know the effect of aeration process on recirculation process $(\mathrm{Q}=100 \mathrm{~mL} / \mathrm{min})$. Figure 5 shows the pattern amount of BOD slightly decrease after 5 hours process. The BOD value after 5 hours of the deposition process for an air rate of $4 \mathrm{~L} / \mathrm{min}$ the concentration becomes $268 \mathrm{mg} / \mathrm{L}$ while for an air rate of $8 \mathrm{~L} / \mathrm{min}$ it becomes $164 \mathrm{mg} / \mathrm{L}$.

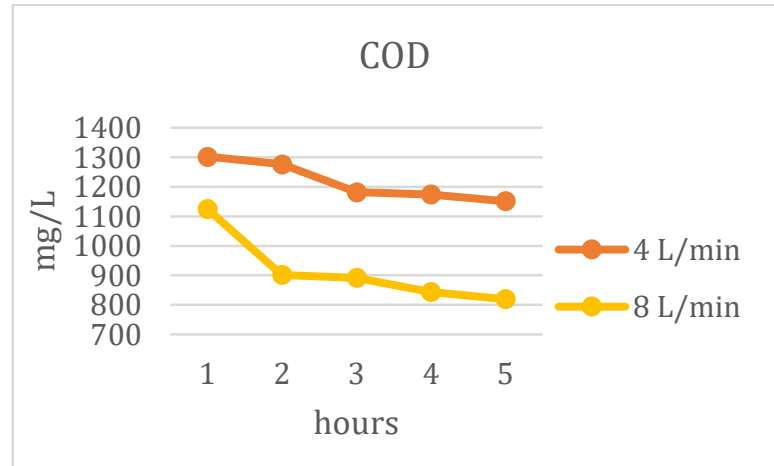

Figure 7. COD Concentration in $4 \mathrm{~L} / \mathrm{min}$ and $8 \mathrm{~L} / \mathrm{min}$ air Flowrate
The pattern from COD concentration air flowrate $4 \mathrm{~L} / \mathrm{min}$ and $8 \mathrm{~L} / \mathrm{min}$ represent almost smiliar pattern with BOD concentration 4 $\mathrm{L} / \mathrm{min}$ and $8 \mathrm{~L} / \mathrm{min}$, but for the COD number shows the significant decreasing number compare to COD result on $8 \mathrm{~L} / \mathrm{min}$ (Figure 7 ). In conditions when the deposition time entered 2 hours, a very significant decrease was seen, this indicates that the most significant time for the decline was 2 hours. This is also the same as Ariyani's report, (2015) reports that if using the activated sludge process, the deposition is better done within 2 hours.

This data can be used in further research to minimize energy that the recycle pump can work every 2 hours and return the sludge aeration reactor in the wastewater treatment.

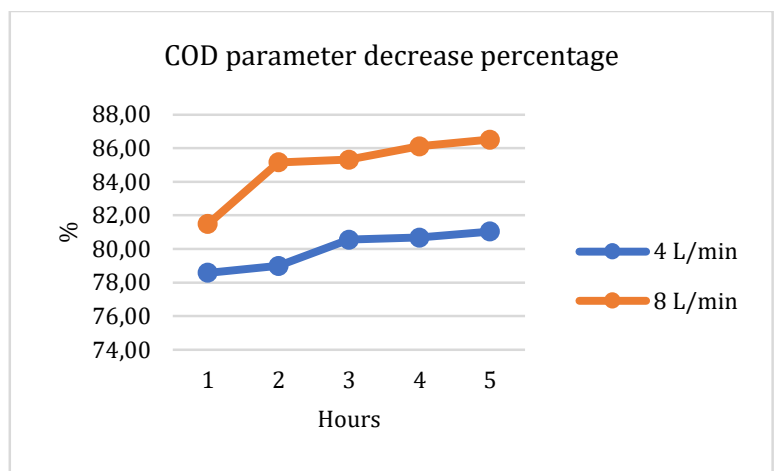

Figure 8. COD Parameter Decrease Percentage

The largest percentage of COD reduction using an air rate of $8 \mathrm{~L} / \mathrm{min}$ is $86.51 \%$ (Figure 8 ). This result is slightly larger than the research by Astuti, (2019) with a decrease in COD of 84.4\%. Because the inlet COD concentration is greater in the range of $7000-8000 \mathrm{mg} / \mathrm{L}$.

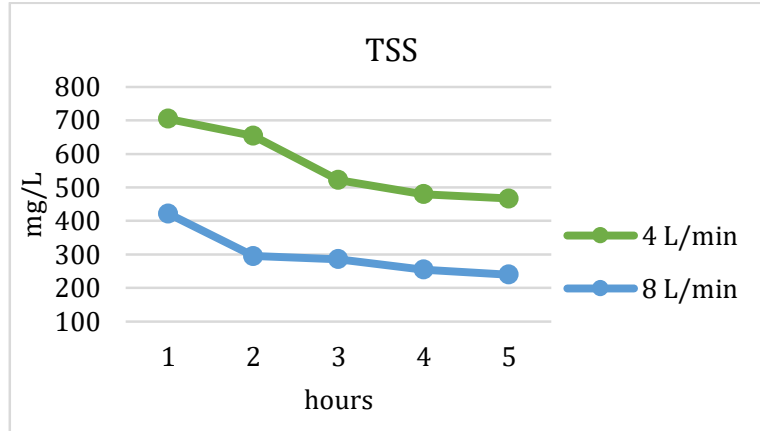

Figure 9. TSS Concentration in $4 \mathrm{~L} / \mathrm{min}$ and $8 \mathrm{~L} / \mathrm{min}$ air Flowrate

The best decrease in TSS concentration at 8L/min air flowrate with significant settling time occurred at 2 hours. Overall best deposition result at 5 hours (Figure 9).

Of all the parameters that were tested, only the $\mathrm{pH}$ parameter still met the quality standard 
in accordance with East Java Governor Regulation No. 72 of 2013. So in connection with this, it is hoped that there will be preliminary processing or final processing.

\section{CONCLUSIONS}

The development of a wastewater treatment process employing microorganism from wastewater appears potential because it does not require the use of a microorganism stater or other media such as glucose. Another factor is that food processing wastewater is better for microorganism cultivation because it includes more valuable nutrients and less poisonous chemicals and harmful elements that interfere with microorganism growth After 7 days of treatment under the same conditions ( $\mathrm{pH}$ and temperature), the Acclimatization process can reach $77.45 \%$. With 5 hours of recirculation at $8 \mathrm{~L} / \mathrm{min}$ air flowrate and $86.51 \%$ COD parameter decrease after the detention time (18 hours), the results of COD number also considerably decrease.

\section{REFERENCES}

Astuti, A. D. and Ayu, D. I, 2019. Treatment of Tofu Industry Wastewater using Bioreactor Anaerobic-Aerobic and Bioball as Media with Variation of Hidraulic Retention Time. Reaktor, Vol. 19 No. 1, March Year 2019, pp. 18-25

Bapedal. 1994. Environmental Insurance. Jakarta : Environmental Impact Control Agency.

East Java Governor Regulation Number 72 of 2013. (2013). Regarding Wastewater Quality Standards for Industry and/or other Business Activities

Ding, J., Zhao, F., Cao, Y., Xing, L., Liu W., Mei, S., Li, S. 2014. Cultivation of Microalgae in Dairy Farm Wastewater without Sterilization. International Journal of Phytoremediation. DOI: 10.1080/15226514.2013.876970.

Faisal, Muhammad et al. Treatment and Utilization of Industrial Tofu in Indonesia. Asian Journal of Chemistry. DOI: 10.14233/ajchem.2016.19372 .

Fitrahani, L. Z. (2012). Characterization Of Operating Conditions And Process Optimization of A Food Industrial Wastewater Treatment Plant. E-Jurnal
Agroindustri Indonesia Oktober, 1(No. 2), p 110 - 117.

N, Sintawardani. 2011. Socio-Economic Problems on Reducing the Wastewater Pollution from Tofu Processing in the Cibuntu Area, Indonesia. Research Center for Physics Indonesian Intitute of Science.

Nagwekar, P. R. (2014). Removal of Organic Matter from Wastewater by Activated Sludge Process-Review. International Journal of Science, Engineering and Technology Research (IJSETR). Vol 3. no. 5: 1260-1263.

Matilda, F., Biyatmoko, D., Rizal, A., Abdulllah. 2016. The Improvement of Quality of Tofu Industry Wastewater Effluent on Activated Sludge System with Flow Rate Variation Using Ironwood (Eusideroxylon zwageri) Activated Charcoal. EnviroScienteae Vol. 12 No. 3, Nopember 2016 page $207-215$

Martin, A. M. P., Heijnen, J. J., Van Loosdrecht, M. C. M., 2003. Effect od Dissolved Oxygen Concentration on Sludge Settleability. Applied Microbiology and Biotechnology. 62, 586-593

Ministry of Environmental RI, Number 15 of 2008 about Water Quality Standards Soybean Processed Industrial Waste.

Ridha, M. 2015. Promoting Eco-Friendly Production in Indonesia Tofu and Tempeh Industry. Impact Sheet-Switch Asia Project.

Shurtleff, William and Aoyagi, Akiko. 1975. The Book of Tofu : Food For Mankind. Autumn Press, Inc., Massachusetts. ISBN : 0-394-73431-9.

Sukma, B. A. and Agus, S.M, 2015. The Ability Mixed Culture Sludge From Industrial Waste Of Crumb Rubber To Ruduce Levels COD, BOD dan TSS. Majalah Biam. Vol. 11, No. 1 Juli 2015, Hal 11-16.

Tan, X., Chu,H., Zhang,Y., Yang, L., Zhao, F., Zhou, F. (2014). Chlorella pyrenoidosa cultivation using anaerobic digested starch processing wastewater in an airlift circulation 
photobioreactor. Bioresource Technology, 170, 538-548. Doi:10.1016/j.biortech.2014.07.086 .

Zahra, S. A., Sumiyati, S., Sutrisno, E., 2015. Reduction of BOD and COD Concentrations in Tofu Liquid Waste with Biofilm Pond Technology Using Fish Net Biofilter Media and Bioball. Environmental Engineering Study Program. Faculty of Engineering, Diponegoro University. 